\title{
Hidraulic potential anomaly indicating thermal water reservoir and gas pool near Berekfürdő, Trans-Tisza Region, Hungary
}

\author{
Brigitta Czauner, Judit Mádl-Szőnyi \\ Department of General and Applied Geology \\ Eötvös Loránd University, Budapest \\ György Pogácsás \\ Department of General and Applied Geology \\ Eötvös Loránd University, Budapest
}

\author{
József Tóth \\ Department of Earth \& Atmospheric Sciences \\ University of Alberta, Edmonton, Canada
}

\begin{abstract}
In the surroundings of Berekfürdő (Trans-Tisza Region) a significant positive anomaly was observed in the fluid potential field, in the course of a regional-scale hydrogeologic study of the Great Hungarian Plain (Tóth and Almási 2001). It was assumed that the cause of this phenomenon could be the presence of structural elements in an overpressured fluid potential field. The seismic, hydraulic and hydrogeochemical evaluation of the anomaly proved the presence of a complex structure. The results furnish an example for the theoretical model of Matthäi and Roberts (1996). The identified faults, which define the basement high and rise close to the surface, represent direction-dependent control over the fluid flow systems of the Study Area. The detected horizontal barrier fault zones may act as lateral seals of the Tatárülés-Kunmadaras gas field and might ensure the active water pressure of the reservoir system. The junction of the vertically conducting and horizontally sealing fault zones near Berekfürdô represent the southern limit of the prolific hydrocarbon-bearing Szolnok and the identified "extra" aquifer. The junction of these faults causes intensive water upwelling which was drilled by Pávai-Vajna in 1928. This exploration initiated the development of the Berekfürdő Spa.
\end{abstract}

Key words: faults, overpressure, hydraulic potential anomaly, seismic interpretation, Trans-Tisza Region

\section{Introduction}

Near Berekfürdő and Kunmadaras a significant positive anomaly (Fig. 1) can be observed in the fluid potential field, in the course of a regional-scale hydrogeologic study of the Great Hungarian Plain, Eastern Pannonian Basin (Tóth and Almási 2001).

\footnotetext{
Addresses: B. Czauner, J. Mádl-Szőnyi, Gy. Pogácsás: H-1117 Budapest, Pázmány P. sétány 1/C, Hungary, e-mail: brigicza@gmail.com J. Tóth: 1-26 Earth Sciences Building, Edmonton, AB T6G 2E3, Canada

Received: September 1, 2008; accepted: November 1, 2008
} 
The anomaly appeared as a "potential plume" on the NNW-SSE oriented (H4) hydraulic cross-section of Tóth and Almási (2001). The "plume" rises from a PreNeogene basement high (-1500 m ASL); its closest approach to the surface is at a depth of 400 m, near Berekfürdő (Fig. 1). Tóth and Almási (2001) explained the development of this phenomenon by hypothesizing the presence of structural elements, which cut through the thick, regionally extensive low-permeability (aquitard) Neogene strata (e.g. Endrőd and Algyő formations). They supposed that, along the hypothetical faults, water-upwelling and overpressure from the basement could dissipate toward the younger and shallower sediments. This assumption was later supported by the gravitational and hydrobotanical investigations of Kiss and Szalma (2007).

The aims of this study were the following: i) structural geology mapping, ii) detailed evaluation of the Berekfürdő fluid potential anomaly, iii) investigation of the hydraulic behavior of seismically identified faults regarding fluid (water, hydrocarbons) hydraulics, and iv) connecting the results to the gas pools and thermal waters of Berekfürdő.

The Study Area is located in the Trans-Tisza Region of the Great Hungarian Plain (Fig. 2). Inside the research area a local-scale Study Area was chosen on the basis of the surface extrapolation of the fluid potential anomaly (Fig. 2). The presence of thermal water pools (discovered at Berekfürdó in the 1920s) and significant gas accumulations (the Tatárülés-Kunmadaras gas field was discovered in the 1950s-1960s) provides a better understanding of the Study Area's hydrogeology.

\section{Hydraulic role of faults}

Faults can both be barriers and conduits for fluid flow, depending on the driving forces of fluids, the permeability of the fault gouge, the permeability and relative position of the formations of the foot wall and hanging wall, the relative orientation of the fault planes, as well as the spatial and temporal variation of these factors (Caine et al. 1996).

In an ideal case the fault zone-related "barriers" have lower permeability than that of the crosscut aquifer, and the flow direction in the aquifer adjacent to the fault tends to be parallel to the plane of the fault. Corroborating evidence for fault-zone barriers are the accumulation of hydrocarbons on one side of the fault, and discontinuities in the formation water chemistry across the fault (Underschultz et al. 2005).

Fig. $1 \rightarrow$

A) H4 hydraulic cross-section (after Tóth and Almási 2001; Fig. 22, p. 30); B) Location of the hydraulic cross-section. 1. Neogene aquifer; 2. Neogene aquitard; 3. Pre-Neogene basement (aquifer); 4. oil accumulation; 5 . gas accumulation; 6 . hydraulic head contours (m ASL); 7. inferred flow direction in the plane of the cross-section; 8 . intersection with other cross-sections; 9. intersection with rivers; 10. Study Area 


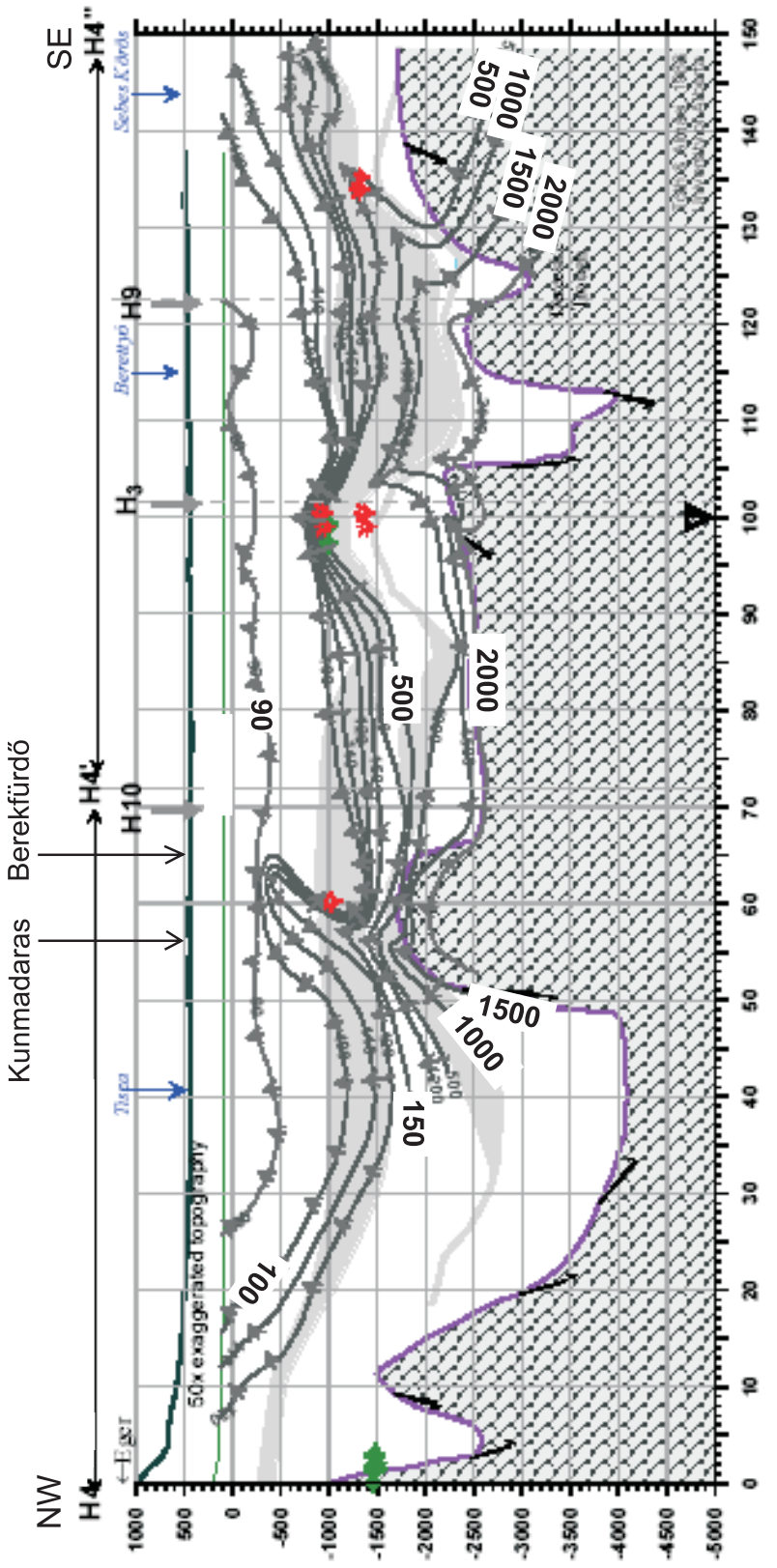

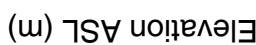

으

$\infty \infty$

$\underset{x \rightarrow \stackrel{8}{\rightarrow}}{\longrightarrow}$

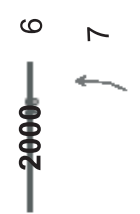

$\nabla \leftarrow 0$

+冲

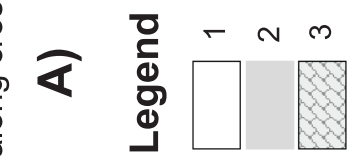


When permeability is higher along the fault than the crosscut aquifer, the fault acts as a conduit and the flow direction in the aquifer adjacent to the fault

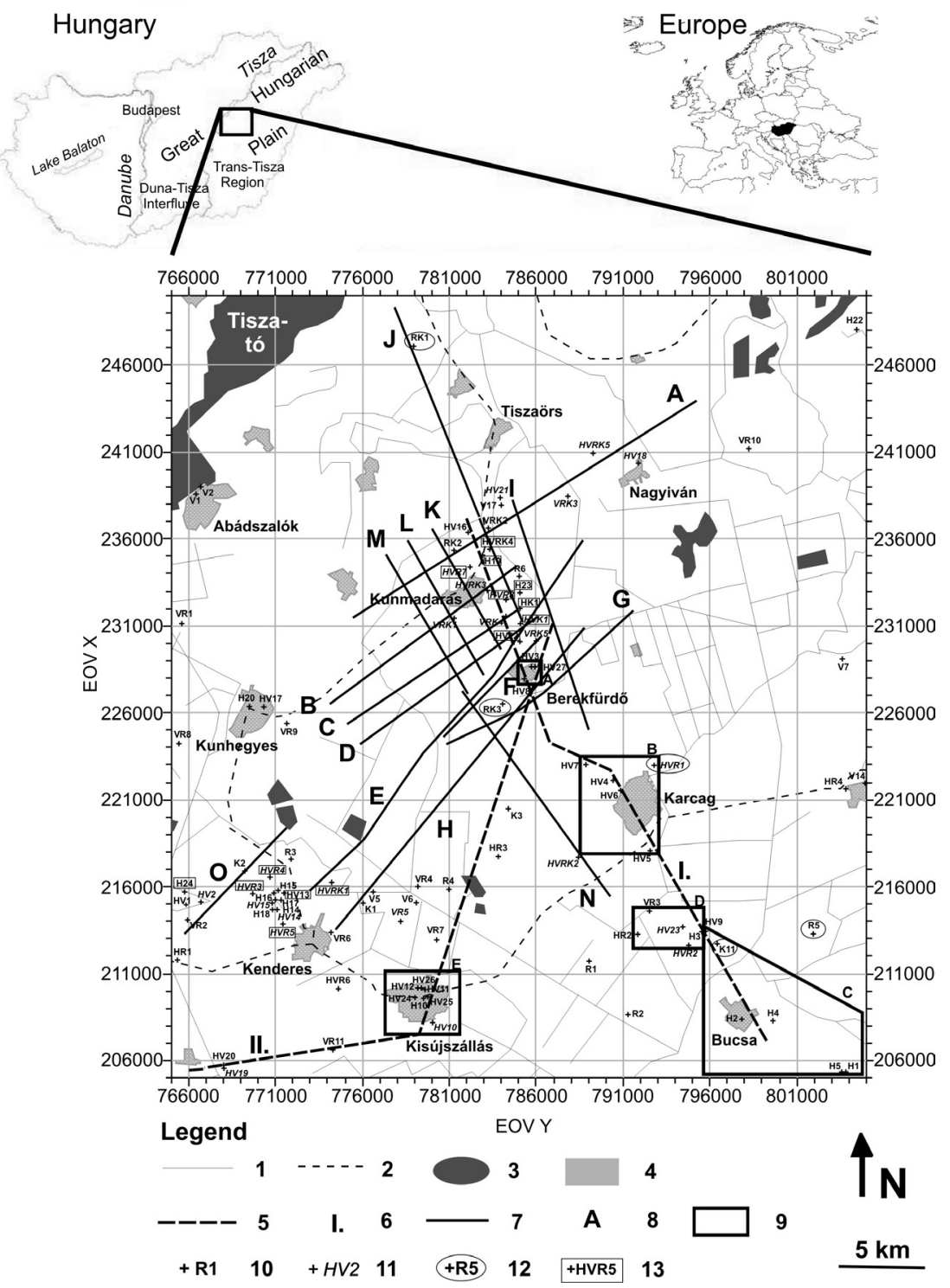

Fig. 2

Location of the Study Area and data sources. 1. river, canal; 2. road; 3. lake; 4. settlement; 5, 6. location and identification code of hydraulic cross-section; 7, 8. trace and identification of seismic section; 9 . areal extent of selected $\mathrm{p}(\mathrm{z})$ profiles 10 . identification code of well $(\mathrm{H}$ - hydraulic, $\mathrm{V}$-hydrochemical, $\mathrm{R}$ - formation classification, $\mathrm{K}$ - well-log data); 11 . data source of density correction; 12 . well with vertical seismic profile; 13. unusable well 
intercepts the plane of the fault (Underschultz et al. 2005). Conduit faults induce equipotential plumes, sacs and ridges (Tóth and Almási 2001) in the potential field. Those faults reaching the surface lead to the appearance of springs with thermal and/or chemical anomalies, and recharging aquifers at depth (Underschultz et al. 2005). All depends on whether the fault is acting as a source or as a sink for fluids.

Matthäi and Roberts (1996) distinguished different cross-sectional models of faulted sand-shale sequences characterized by pressure-driven fluid flow systems. In the case of conduit fault (Fig. 3) the direction of fluid flow in the upper hanging wall sand is outward of the fault plane. Thus no fluid flow occurs across the fault because the fluid flows out of the fault into the intersected sands. In this sense a conduit fault might be acting as a fluid flow direction-dependent barrier.
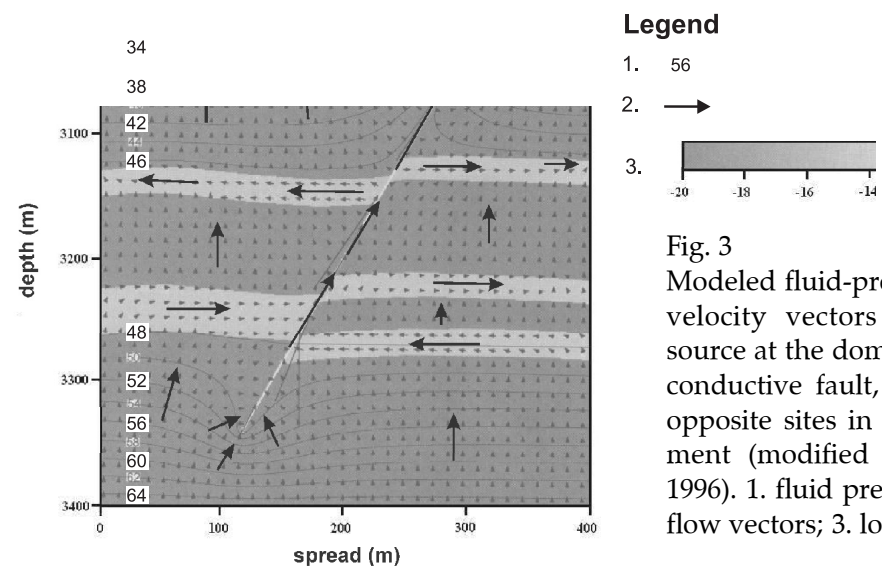

Fig. 3

Modeled fluid-pressure isobars and fluid-flow velocity vectors generated by a pressure source at the domain's base in the vicinity of a conductive fault, with displaced aquifers on opposite sites in a low-permeability environment (modified from Matthäi and Roberts 1996). 1. fluid pressure isobars (MPa); 2. fluidflow vectors; 3 . $\log$ permeability $\left(\mathrm{m}^{2}\right)$

\section{Hydrotectonics and hydrostratigraphy}

Applied methods

In this work the method of Mészáros (2005), which was developed for the hydrogeologic investigation of the western shallower margin of the DanubeTisza Interfluve, was applied and further developed to study the relationship between fluid potential anomalies as well as tectonic and sedimentary structures. Fifteen digital seismic sections (see location of seismic lines in Fig. 2) and well logs were used to interpret the hydrotectonics and hydrostratigraphy of the Study Area. MOL Hungarian Oil and Gas Plc kindly provided a Landmark workstation for the joint hydrostratigraphic interpretation of hydraulic, seismic and well data. Lithostratigraphic subdivision data of Juhász (1992) proved to be very useful during the hydrostratigraphic interpretation of the available well logs (Fig. 3.2). 
Results

Three fault zones were seismically identified and mapped, which could facilitate the fluid conduit connection between the overpressured Pre-Neogene basement and the shallower aquifers characterized mainly by gravity-driven flow (Fig. 4). Two of them (Nos 9 and 10 in the legend of Fig. 4) - being located on the

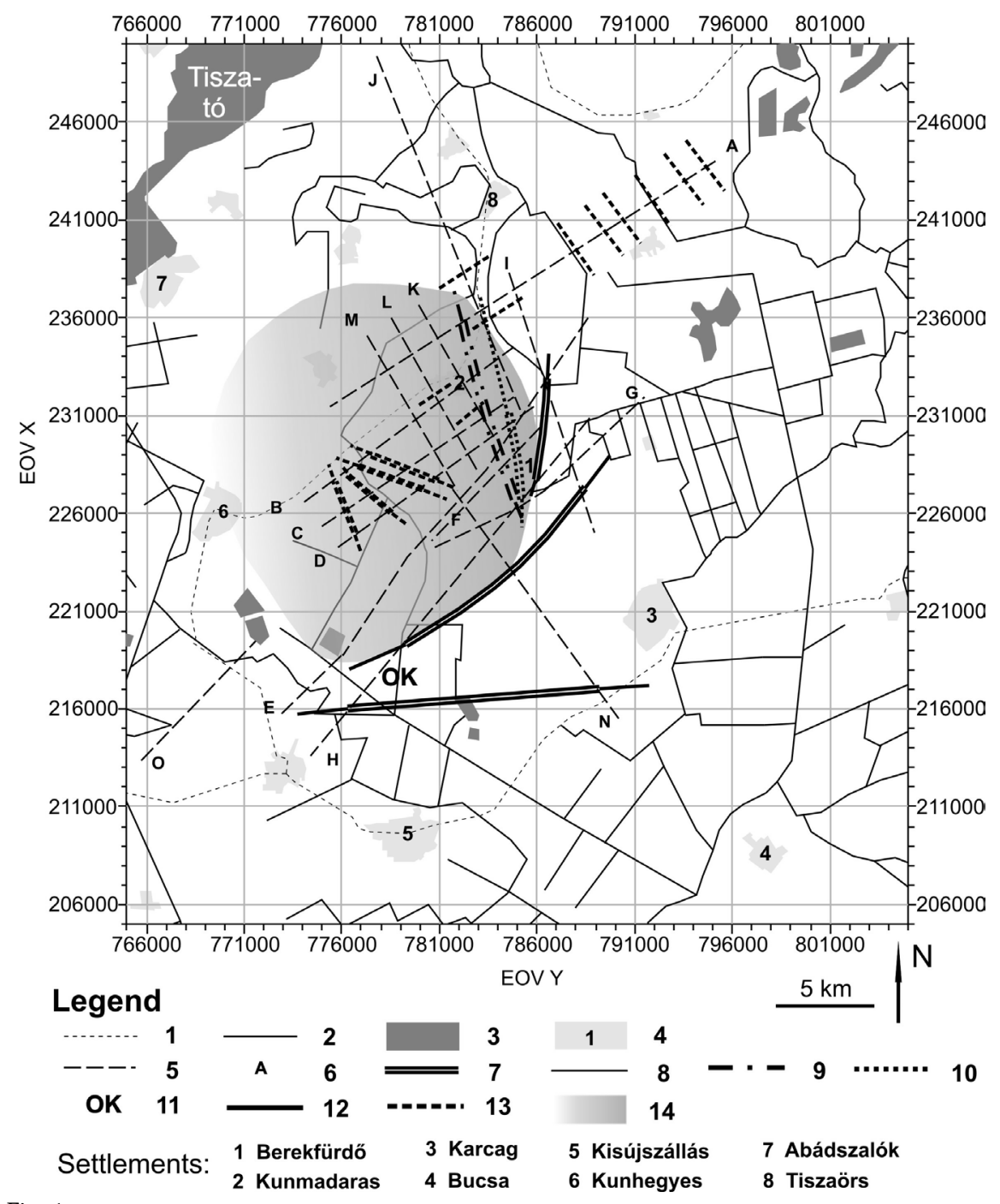

Fig. 4

Principal structural elements identified at $400 \mathrm{~ms}$ (-250 m ASL). 1. road; 2. river, channel; 3. lake; 4. settlement; 5, 6. trace and sign of seismic section; 7. identified fault; 8 . supposed fault; 9,10 . strike-slip faults along the basement maximum; 11. Orgovány-Kisújszállás strike-slip fault zone; 12. basement fault; 13. fault independent of basement; 14. extent of the "extra" aquifer 
eastern and western margin of a N-S trending basement high intersect each other south of Berekfürdô, at a depth of about $1200 \mathrm{~ms}$ (-1180 m ASL). In the southern part of the research area (Fig. 4) a SW-NE trending wrench fault was identified. It belongs to the almost $200 \mathrm{~km}$-long Paks-Orgovány-Kisújszállás strike-slip fault zone (Pogácsás et al. 1989). According to Lórincz et al. (2002) the most significant neotectonic zones of Hungary are located at the boundary of two terranes. Between the northwestern (ALCAPA) terrane and the southeastern (TISZA) terrane more than $100 \mathrm{~km}$ of right-lateral displacement occurred in the Early Miocene (Csontos et al. 1992). The magnitude of the Late Miocene (Pannonian) lateral displacement was 8 to 10 kilometers along the Kiskőrös segment of the Paks-Kisújszállás wrench zone (Pogácsás et al. 1989). Quaternary reactivation of the Paks-Kisújszállás wrench zone was proved by high resolution seismic survey on the Danube river (Tóth and Horváth 1997). Lórincz et al. (2002) estimated the magnitude of the left lateral Quaternary horizontal displacement to be as high as 1 to $5 \mathrm{~km}$ at the Szolnok segment of the wrench zone.

The thick Neogene sediments of the Pannonian Basin have been subdivided into five hydrostratigraphic units (Tóth and Almási 2001; Mészáros 2005; MádlSzônyi and Tóth 2009) (Fig. 5).

As a consequence of the recent Berekfürdô seismic and well-log hydrostratigraphic analysis two more units could be identified in the Study Area. One of them is an argillaceous aquitard unit on the top of the Szolnok Aquifer, and the other is a sandy aquifer unit between the new aquitard and the Algyő Aquitard. They are tectonically bounded (strike-slip fault) to the east and south but their extent to the north and to the west is unknown (Fig. 4).

The Tatárülés-Kunmadaras gas field accumulated in these Lower Pannonian sandstone reservoirs. It is considered that these hydrocarbon-bearing turbiditic sandstone groups represent the extra aquifer unit and the Szolnok Aquifer. The hydrocarbon pools within these units are located above a basement high, between the two strike-slip fault zones.

\section{Hydraulics and hydrochemistry}

\section{Data processing}

The filtering and qualifying of hydraulic and water chemical data was the first step of the data processing because of their unfavorable quality and deficient quantity. After filtering and ranking the data, 61 hydraulic (pore-pressure and stabilized water level) data of 50 wells were chosen for further evaluation. During the hydraulic processing density correction was applied (Czauner 2008). From the numerous hydrochemical data only the $\mathrm{Na}^{+}, \mathrm{Cl}^{-}$and $\mathrm{H}_{2} \mathrm{SiO}_{3}$ data were chosen. These indicate and/or show the strongest correlation with the origin (from basement or Neogene sediment) and subsurface residence time of groundwater. Altogether 184 analyses of 74 wells were selected. 


\begin{tabular}{|c|c|c|c|c|}
\hline \multicolumn{2}{|c|}{ Age } & $\begin{array}{l}\text { Lithostratigraphic units } \\
\text { of the research area } \\
\text { (Juhász 1992) }\end{array}$ & $\begin{array}{c}\text { Hydrostratigraphic units } \\
\text { in the Great Hungarian Plain } \\
\text { (Tóth and Almási 2001, } \\
\text { Mádlné Szönyi and Tóth 2007) K (m/s) } \\
\end{array}$ & $\begin{array}{l}\text { Hydrostratigraphic units } \\
\text { of the research area } \\
\text { (Czauner 2008) }\end{array}$ \\
\hline \multirow{9}{*}{ 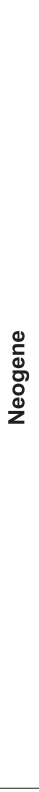 } & 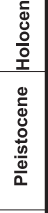 & $\begin{array}{l}\text { Quaternary } \\
\text { Nagyalföld Fm. }\end{array}$ & \multirow[t]{3}{*}{$\begin{array}{l}\text { Nagyalföld Aquifer } \\
\qquad 10^{-5}\end{array}$} & \multirow[t]{3}{*}{$\begin{array}{c}\text { Nagyalföld } \\
\text { Aquifer }\end{array}$} \\
\hline & 这 & Zagyva Fm. & & \\
\hline & $\frac{\circ}{\bar{a}}$ & Újfalu Fm. & & \\
\hline & \multirow{5}{*}{ 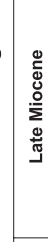 } & \multirow{2}{*}{ Algyő Fm. } & \multirow{2}{*}{ Algyő Aquitard $10^{-8}-10^{-7}$} & Algyő Aquitard \\
\hline & & & & sandy aquifer \\
\hline & & \multirow{2}{*}{ Szolnok Fm. } & \multirow{2}{*}{ Szolnok Aquifer $10^{-7}-10^{-6}$} & argilliferous aquitard \\
\hline & & & & Szolnok Aquifer \\
\hline & & Endröd Fm. & Endrőd Aquitard $10^{-9}$ & Endrőd Aquitard \\
\hline & \multirow[t]{2}{*}{ 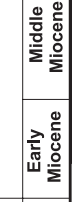 } & $\begin{array}{l}\text { Pre-Pannonian } \\
\text { formations }\end{array}$ & $\begin{array}{l}\text { Pre-Pannonian Aquifer } \\
\qquad 10^{-6}\end{array}$ & Pre-Pannonian Aquifer \\
\hline 9 & & \multicolumn{3}{|c|}{ Hiatus } \\
\hline 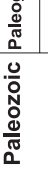 & 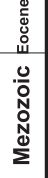 & $\begin{array}{l}\text { Pre-Neogene } \\
\text { formations }\end{array}$ & $\begin{array}{l}\text { Pre-Neogene Aquifer } \\
\qquad 10^{-8}-10^{-7}\end{array}$ & Pre-Neogene Aquifer \\
\hline
\end{tabular}

Fig. 5

Identified hydrostratigraphic units of the Study Area (using data of Juhász 1992; Tóth and Almási 2001; Mádlné Szőnyi and Tóth 2007)

\section{Results}

The five created pressure-elevation sections (Fig. 6) show the deep energy source, which causes significant overpressure in the Pre-Pannonian Aquifer and Endrőd Aquitard, and leads to fluid-upwelling. Most of this energy is dissipated while the fluids flow across the Endród Aquitard, but moderate overpressure appears even in the Algyó Aquitard. Due to the quality and quantity of the available data, the pressure regime of the Great Plain Aquifer is a little bit uncertain, but it could be characterized as close to hydrostatic.

In the hydraulic cross-sections (Fig. 7) stationary fluid flow field could not be seen, partly because of the lack of data and also because of the fluid potential 


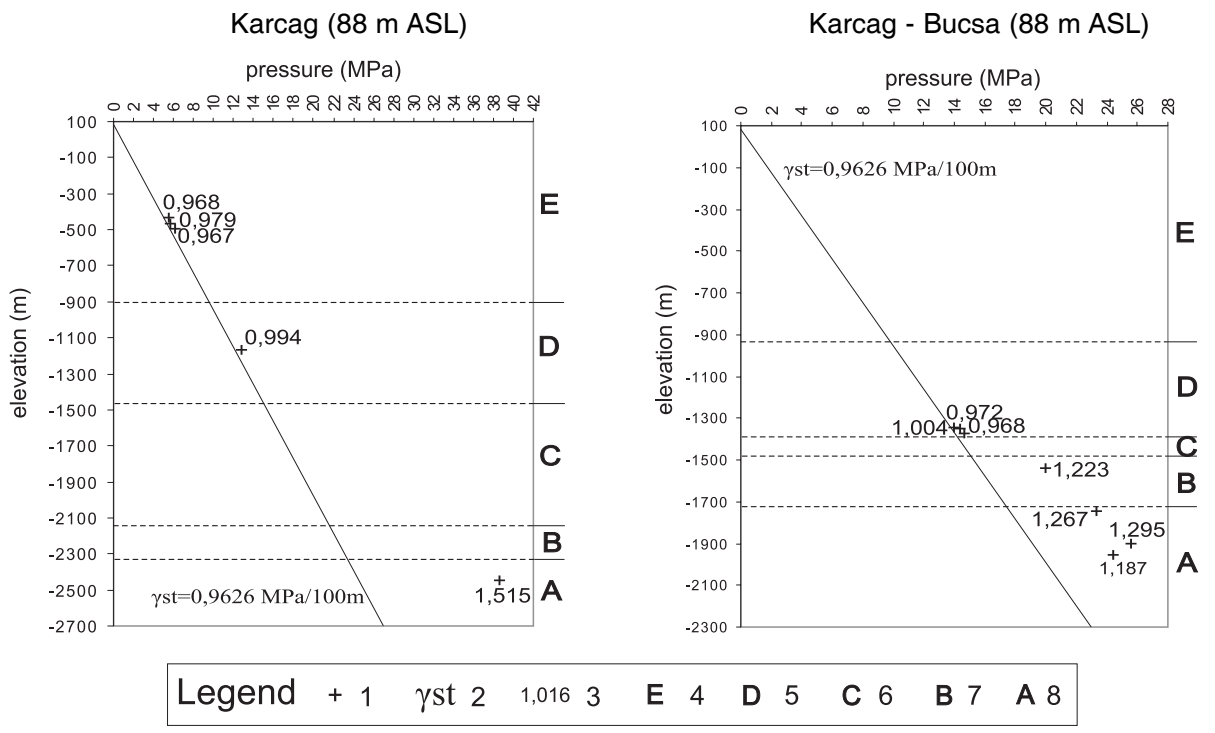

Fig. 6

Two representative examples from the five created pressure-elevation sections. 1 . data point; 2 . vertical hydrostatic pressure gradient; 3. vertical pressure gradient $(\mathrm{MPa} / 100 \mathrm{~m}) ; 4$. Great Plain Aquifer; 5. Algyő Aquitard; 6. Szolnok Aquifer; 7. Endrőd Aquitard; 8. Pre-Pannonian Aquifer

reducing effect of gas and water production. On the other hand, where a boundary surface could be assigned, beneath this surface the system is overpressured, and above it the system is approximately hydrostatic (within the limits of analytical error). The peak of this "overpressure front" coincides with the basement high and the junction of fault zones, south of Berekfürdô.

In the course of hydrochemical analysis the depth distribution of normalized $\mathrm{Na}^{+}, \mathrm{Cl}^{-}$and $\mathrm{H}_{2} \mathrm{SiO}_{3}$ values were compared (Fig. 8). The high $\mathrm{H}_{2} \mathrm{SiO}_{3}$ (max. 226.2 $\left.\mathrm{mgL}^{-1}\right), \mathrm{Na}+\left(\max .23 .4 \mathrm{gL}^{-1}\right)$ and $\mathrm{Cl}^{-}\left(\max .36 .1 \mathrm{gL}^{-1}\right)$ values indicate a deep, basement source. This observation correlates with the seismically interpreted basement faults, most of which terminate upward around (-1300) m ASL. The low $\mathrm{Na}^{+}$and $\mathrm{Cl}^{-}$values $\left(0-1.0 \mathrm{gL}^{-1}\right.$, ) indicate mixing with meteoric water and correlate with the Pannonian or younger growth fault zones.

\section{Conclusion}

The two fault zones, which originate at the basement high in the KunmadarasBerekfürdő region, act as a conduit for fluids in a vertical direction. Thus, they might induce the "potential plume" in the fluid potential field (Fig. 9). However, the eastern fault (zone) acts as a barrier for horizontal fluid flow, due to the different permeability of the Endrőd, Szolnok and Algyő Formations in the footwall and the hanging wall. In the case of the western fault (zone), there is no 
I.

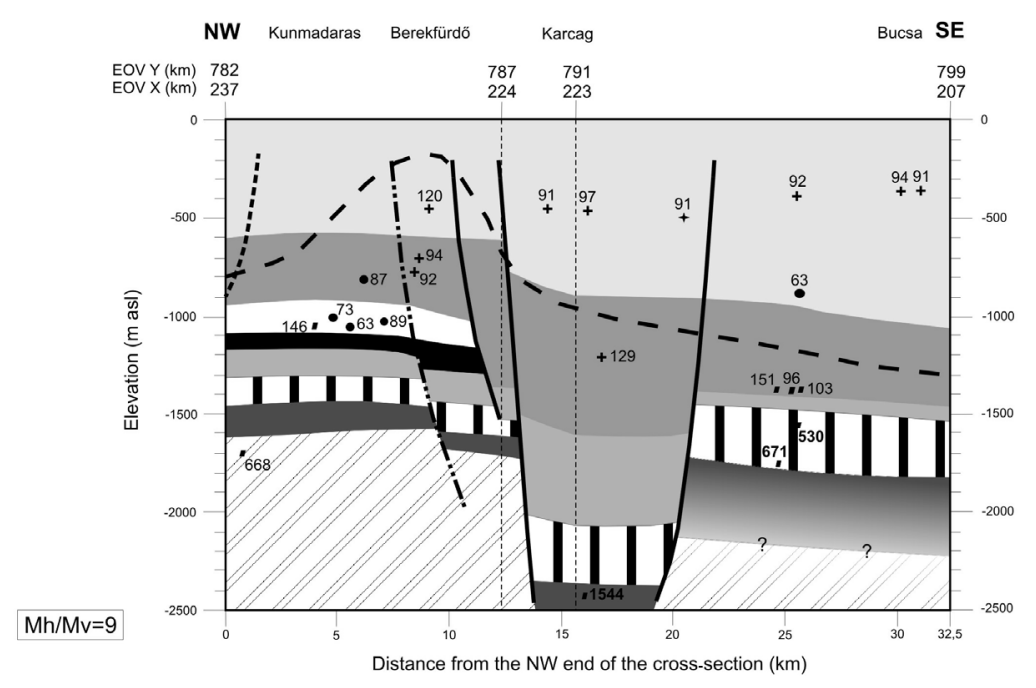

II.

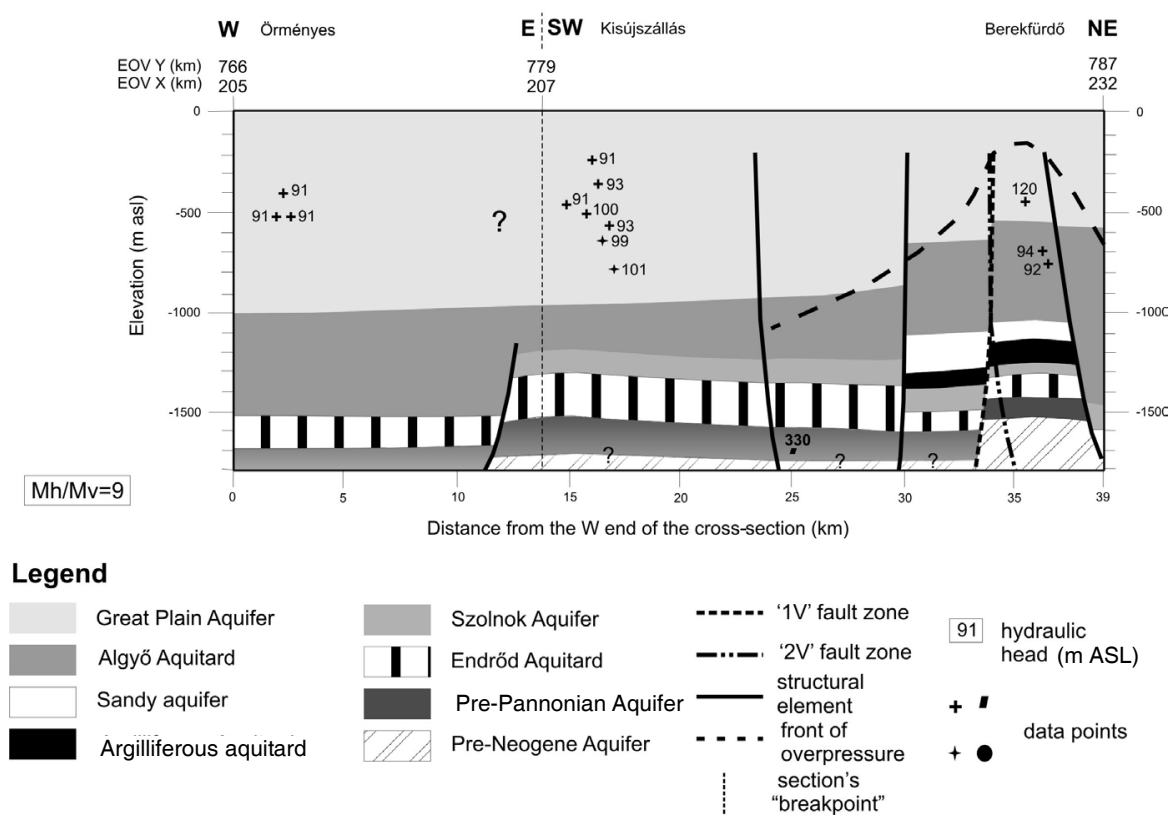

Fig. 7

Hydraulic cross-sections 


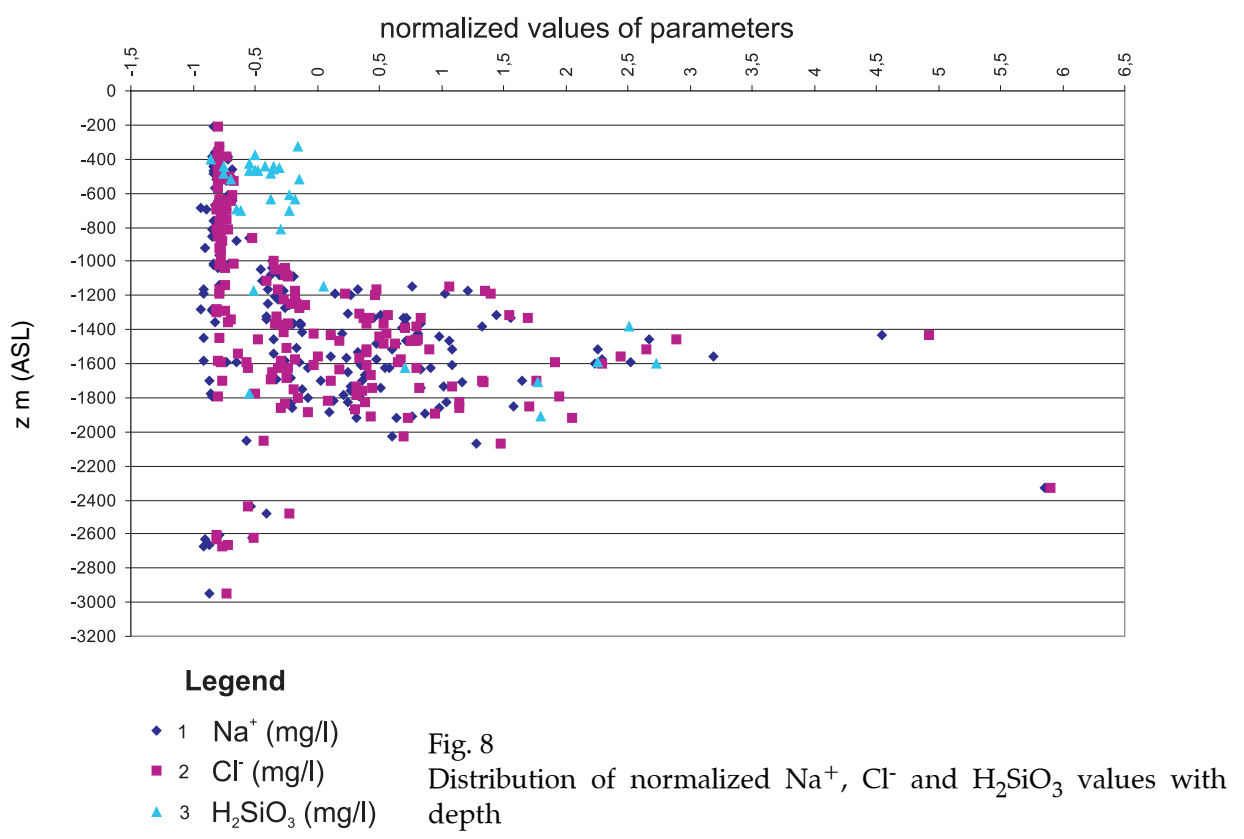

fluid flow across the vertical conduit fault, because the upward-flowing fluid flows out of the fault zone into the intersected sands of the Szolnok Formation and the "extra" aquifer unit (Fig. 9). This result seems to verify the theoretical model of Matthäi and Roberts (1996) (Fig. 3), and correlates fairly well with the hydrochemical data. The horizontal barrier fault zones may act as lateral seals of the Tatárülés-Kunmadaras gas field and could ensure the active water pressure of the reservoir system. On the other hand, the junction of the vertically conducting and horizontally sealing fault zones near Berekfürdó represents the southern limit of the prolific hydrocarbon-bearing Szolnok and "extra" aquifer. The junction of these faults causes intensive water upwelling. The southern border of the gas field and the location of the top of the "potential plume" (near Berekfürdô) are the consequences of the above-mentioned structural and stratigraphic framework.

\section{Summary}

Basement fault zones were identified and mapped on several seismic lines near Kunmadaras and Berekfürdő. Seismic evidence indicates that these faults approach the surface. The heterogeneity of the Algyő Aquitard has been established. Fluid potential data proved the presence of overpressure in the PreNeogene basement and indicated an induced positive fluid potential anomaly ("potential plume") in the Upper-Pannonian strata near Berekfürdő. The presence 
of NaCl-type water upwelling with high $\mathrm{H}_{2} \mathrm{SiO}_{3}$ content was confirmed. This observation correlates with the basement faults, most of which do not approach the surface. The deeper saline water mixes with meteoric water at shallower depth. The identified faults, which originate at the basement high and approach the surface, represent direction-dependent control over the fluid flow systems,

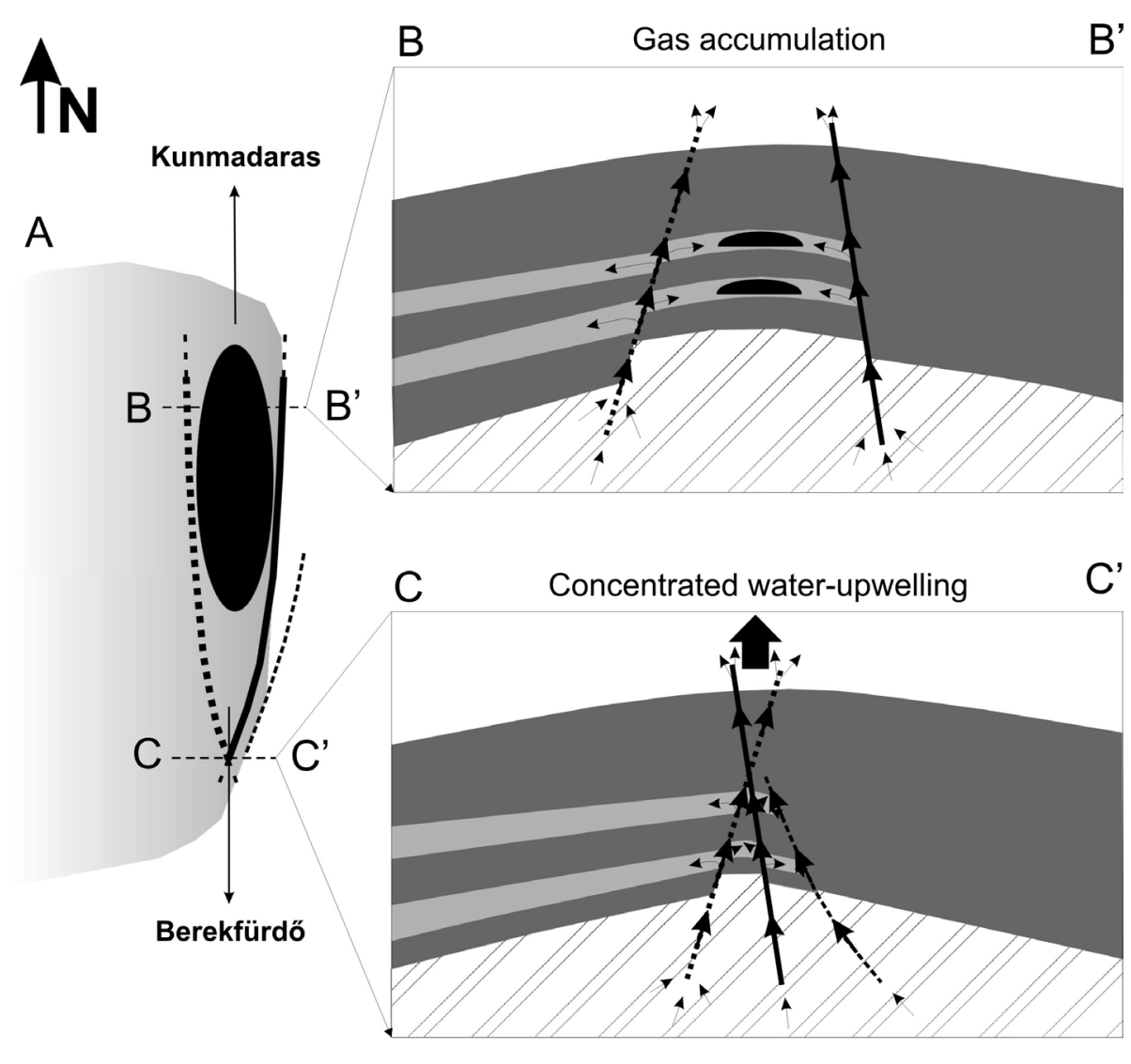

\section{Legend}

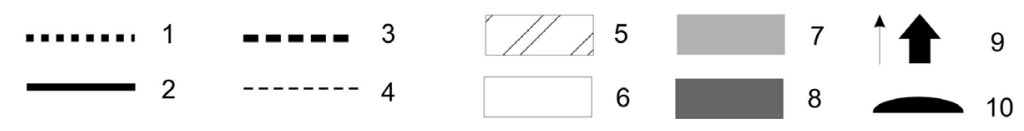

Fig. 9

Diagram of interpreted phenomena in the Study Area. A) The Local Study Area in top view BB', CC': Cross-sections from the northern and southern parts of the local research area. 1, 2. strike-slip master faults; 3 . reverse fault; 4 . trace of cross-section; 5 . Pre-Neogene basement; 6-7. aquifer units (note the "extra" aquifer unit on the map 'A'); 8. aquitard units; 9. fluid flow direction; 10. gas field 
cause deep-water upwelling and could contribute to the development of the petroleum fields of the Study Area. Ferenc Pávai-Vajna succeeded in drilling into this "potential plume" (1928) and initiated the development of the Berekfürdó Spa.

\section{Acknowledgements}

The study was carried out with the support of the Hungarian Oil and Gas Company Plc (MOL Nyrt.) and based on their data within the scope of B. Czauner's MSc thesis. The authors appreciate the involvement of Prof. I. Müller in the research and are also grateful to Dr. Gy. Juhász for making available her formation classification of drilled strata relative to the Study Area. Dr. P. Molnár is also greatly thanked for the review of the paper.

\section{References}

Csontos, L., A. Nagymarosy, F. Horváth, M. Kovác 1992: Tertiary evolution of the Intra-Carpathian area: a model. - Tectonophysics, 208, pp. 231-241.

Caine, J.S., J.P. Evans, C.B. Forster 1996: Fault zone architecture and permeability structure. Geology, 24/11, pp. 1025-1028.

Czauner, B. 2008: Vetők hidraulikai viselkedésének komplex vizsgálata Berekfürdő térségében (Complex research of hydraulic behaviour of faults near Berekfürdő). - MSc Thesis, ELTE Dept of Physical and Applied Geology, Budapest, 165 p. (In Hungarian.)

Juhász, Gy. 1992: A pannóniai (s.l.) formációk térképezése az Alföldön: elterjedés, fácies és üledékes környezet (Pannonian s.l. formations in the Hungarian Plain: distribution, facies and sedimentary environments). - Földtani Közlöny, 122/2-4, pp. 133-165. (In Hungarian.)

Kiss, J., E. Szalma 2007: Tündérrózsák és a gravitációs tér? (Water-lily and the gravity field?) Magyar Geofizika, 48/2. (In Hungarian.)

Lőrincz, K, F. Horváth, G. Detzky 2002: Neotectonics and its relation to the Mid-Hungarian Mobile Belt. - EGU Stephan Müller Special Publication Series 3, pp. 247-266.

Mádl-Szőnyi, J., J. Tóth 2009: A hydrogeological type section for the Duna-Tisza Interfluve, Hungary. - Hydrogeology Journal. DOI: 10.1007/s10040-008-0421-z.

Matthäi, S.K., S.G. Roberts 1996: The influence of fault permeability on single-phase fluid flow near fault-sand intersections: results from steady-state high resolution models of pressure-driven fluid flow. - AAPG Bulletin, 80/11, pp. 1763-1779.

Mészáros, E. 2005: Hidrogeológiai célú szeizmikus értelmezés a Duna-völgy északkeleti részén (Seismic interpretation for hydrogeological purposes on the NE part of Danube-valley). - MSc Thesis, ELTE Dept. of Applied and Environmental Geology, 84 p. (In Hungarian.)

Pogácsás, Gy, L. Lakatos, A. Barvitz, G. Vakarcs, Cs. Farkas 1989: Pliocén-kvarter oldaleltolódások a Nagyalföldön (Pliocene-Quaternary strike-slip faults in the Great Hungarian Plain). Általános Földtani Szemle, 24, pp. 149-169. (In Hungarian.)

Tóth, T., F. Horváth 1997: Neotectonic investigations by high resolution seismic profiling. - In: Marosi, S., A. Meskó (Eds): Seismic safety of the Paks nuclear power plant. - Academical Press, Budapest, pp. 123-132.

Tóth, J., I. Almási 2001: Interpretation of observed fluid potential patterns in a deep sedimentary basin under tectonic compression: Hungarian Great Plain, Pannonian Basin. - Geofluids, 1, pp. $11-36$.

Underschultz, J.R., C.J. Otto, R. Bartlett 2005: Formation fluids in faulted aquifers: examples from the foothills of Western Canada and the North West Shelf of Australia. - In: Boult, P., J. Kaldi (Eds): Evaluating fault and cap rock seals, AAPG Hedberg Series 2, pp. 247-260. 